\title{
Communicative Language Teaching: Possibilities and Problems
}

\author{
Pusuluri Sreehari ${ }^{1}$ \\ ${ }^{1}$ Department of English, Al-Jouf University, Saudi Arabia \\ Correspondence: Pusuluri Sreehari, Assistant Professor of English, Department of English, Al-Jouf University, \\ Saudi Arabia. E-mail: sreehari125@gmail.com
}

Received: September 16, 2012 Accepted: October 9, 2012 Online Published: October 19, 2012

doi:10.5539/elt.v5n12p87 URL: http://dx.doi.org/10.5539/elt.v5n12p87

\begin{abstract}
This paper investigates the teaching of English at undergraduate colleges in the state of Andhra Pradesh, India in the backdrop of Andhra Pradesh English Lecturers' Retraining Program. The program was jointly sponsored and conducted by the Directorate of Collegiate Education, Government of AP and the US State Department English Language Fellow Program. The main aim of the program was to update the teaching skills of English teachers of undergraduate colleges in the State. The program trained teachers to adopt Communicative Language Teaching (CLT) principles so as to enhance English language skills of their students. The paper attempts to identify the possibilities and problems in the implementation of CLT principles and techniques in these colleges. The results indicate that teachers should follow more learner centered ways in their teaching of English.
\end{abstract}

Keywords: teaching of English, English communication skills, CLT principles and techniques

\section{Introduction}

Language has been viewed differently at different times by Linguists and Applied Linguists. It has been thought variously - as a system, as a skill and as a means of communication. In Communicative Language Teaching (CLT), "language teaching is based on a view of language as communication, that is, language is seen as a social tool which speakers use to make meaning; speakers communicate about something to someone for some purpose, either orally or in writing" (Berns, 1990). In India, until recently, English has been regarded as yet another subject in schools and colleges. The structural method has been used in the teaching of English. The predominant role of the teacher has been to lecture about various aspects of the English language. The learner has been treated as the passive recipient of doses of language learning. Even the materials have also been produced keeping in view this particular conception. Structural competence has been given predominance over communicative competence. Accuracy in language production has been preferred to fluency and ability to converse in various situations.

Most Indians now strongly feel that English has the potential to make people employable. It has become the most sought after language in India as a result of increase in the Business Process Outsourcing projects and Call Centre jobs. Since the English language is intended to be used in Andhra Pradesh, especially by the undergraduate learners for enhancing career prospects and everyday communication, the government of AP tried to address these aspirations by upgrading the teaching skills of the undergraduate teachers of English through the Retraining Program. The program was jointly sponsored and conducted by the Directorate of Collegiate Education, Government of AP and the US State Department English Language Fellow Program.

\section{Review of Related Literature}

\subsection{The Communicative Approach (CA) or Communicative Language Teaching (CLT)}

India has had a long tradition of English language teaching. Many methods such as Grammar Translation Method, Structural Approach, and Direct Method have been tried out. However, they have failed to enable learners to use English for practical benefits (e.g. to get a job) and everyday communication. In the recent years, many teachers in India have embraced the concept of CLT to meet their students' English language demands.

Communicative Language Teaching originated in Britain in the 1960s as a replacement to the earlier structural method. Richards and Rogers (1986, p. 154) mentioned: "The work of the Council of Europe; the writings of Wilkins, Widdowson, Candlin, Christopher Brumfit, Keith Johnson, and other British applied linguists on the theoretical basis for a communicative or functional approach to language teaching; the rapid application of these 
ideas by textbook writers; and the equally rapid acceptance of these new principles by British language teaching specialists, curriculum development centers, and even governments gave prominence nationally and internationally to what came to be referred to as the Communicative Approach, or simply Communicative Language Teaching."

Widdowson (1990, p.159) described Communicative Approach as follows: “...it concentrates on getting learners to do things with language, to express concepts and to carry out communicative acts of various kinds. The content of a language course is now defined not in terms of forms, words and sentence patterns, but in terms of concepts, or notions, which such forms are used to express, and the communicative functions which they are used to perform."

\subsection{Principles/Features of CLT}

The communicative approach is rather broad-based and it is most often defined as a list of general principles or features. Nunan's (1991) five features of CLT include:

i. An emphasis on learning to communicate through interaction in the target language.

ii. The introduction of authentic texts into the learning situation.

iii. The provision of opportunities for learners to focus, not only on language but also on the learning process itself.

iv. An enhancement of the learner's own personal experiences as important contributing elements to classroom learning.

v. An attempt to link classroom language learning with language activities outside the classroom.

\subsection{Communicative Competence}

CLT focuses on improving learners' communicative competence. The concept of communicative competence was originally developed in the early 1970s by the sociolinguist Hymes. It was then further developed in the early 1980s by Canale and Swain. According to Canale (1983), communicative competence refers to "the underlying systems of knowledge and skill required for communication". Canale and Swain (1980, p. 4) defined communicative competence in terms of four components:

i. grammatical competence: words and rules

ii sociolinguistic competence: appropriateness

iii discourse competence: cohesion and coherence

iv strategic competence: appropriate use of communication strategies

Bachman (1990, p. 5) divides communicative competence into the broad headings of "organizational competence," which includes both grammatical and discourse (or textual) competence, and "pragmatic competence," which includes both sociolinguistic and "illocutionary" competence.

Kiato and Kiato (1996, p. 1) observed that "the basic idea of communicative competence remains the ability to use language appropriately, both "receptively and productively, in real situations".

Communicative competence, according to Richards $(2006$, p. 3) includes the following aspects of language knowledge:

i Knowing how to use language for a range of different purposes and functions

ii Knowing how to vary our use of language according to the setting and the participants (e.g., knowing when to use formal and informal speech or when to use language appropriately for written as opposed to spoken communication)

iii Knowing how to produce and understand different types of texts (e.g., narratives, reports, interviews, conversations)

iv Knowing how to maintain communication despite having limitations in one's language knowledge (e.g., through using different kinds of communication strategies)

\subsection{Types of Learning Activities and Techniques}

In communicative classes, a wide variety of activities such as role plays, interviews, discussions, information gap activities, language games, language learning simulations, problem solving tasks, quizzes, and surveys are used. The focus is usually on developing language skills and functions in authentic contexts. Littlewood (1981) distinguishes two major activity types-functional communication activities and social interaction activities. 
Functional communication activities are aimed at developing certain language skills and functions, which involve communication. Social interaction activities include conversation and discussion sessions, use of dialogues and role plays.

\subsection{The Use of Authentic Materials}

The role of a teacher in a communicative classroom is to facilitate language learning in meaningful ways. To achieve this end, most communicative classrooms make use of authentic materials. The use of authentic materials serves as a chief aid to creating an authentic context in which learners can develop their communicative competence. Materials that give learners a feel of using real life language are called authentic materials. According to Nunan (1989, p. 54), 'A rule of thumb for authentic material is any material which has not been specifically produced for the purposes of language teaching.' The main idea of using them in the classroom is to familiarize the learners with the language needed in real life. Authentic materials can include audio, audiovisual and printed materials. Examples of these include TV news and programs, TV and radio commercials, music, movies, announcements at public places such as railway stations, airports, supermarkets, newspapers, magazines, photographs, paintings, drawings, stamps, currencies, restaurant menus, street signs, product labels, tourist information brochures, catalogues, telephone books, greeting cards, letters, memos, circulars, minutes of the meetings, reports, billboards, notices, forms such as applications and tax forms, podcasting on the internet and web based programs involving multimedia use. Teachers should select authentic materials keeping in view the needs and interest, language learning goals, cultural appropriateness and level of language of the specific group of learners.

\subsection{Roles of Teachers and Students in CLT}

On the roles of teacher and students in a communicative classroom, Larsen-Freeman (1986, p. 131) observes that "The teacher facilitates communication in the classroom. In this role, one of his major responsibilities is to establish situations likely to promote communication. During the activities he acts as an adviser, answering student's questions and monitoring their performance. He might make note of their errors to be worked on at a later time during more accuracy-based activities. At other times he might be a 'co-communicator' engaging in the communicative activity along with students. Students are, above all, communicators. They are actively engaged in negotiating meaning - in trying to make themselves understood and in understanding others - even when their knowledge of the target language is incomplete. Also, since the teacher's role is less dominant than in a teacher-centered method, students are seen as more responsible managers of their own learning."

Commenting on the nature of student-teacher interaction and the student-student interaction, Larsen-Freeman (1986, p. 133) says: "The teacher may present some part of the lesson, such as when working with linguistic accuracy. At other times, he is the facilitator of the activities, but he does not always himself interact with the students. Sometimes he is a co-communicator, but more often he establishes situations that prompt communication between and among the students. Students interact a great deal with one another. They do this in various configurations: pairs, triads, small groups, and whole group."

\subsection{Limitation and Significance of CLT}

Lindsay and Knight (2006, p. 23) commented that "CA is very widely used all over the world. It has shifted the focus in language teaching from learning about the language to learning to communicate in the language. However, there are problems associated with it. ... The most serious criticism of CA is that it is not as effective as it claims to be". ELT practitioners in countries such as India should not forget the fact that CA was developed in Britain, the United States and other English-speaking countries. Therefore, its application in countries such as India will not be an easy task. Teachers and learners should be flexible enough to follow the practices implicit in CLT. However, they should not abandon CLT altogether. Teachers have to realize that they can meet the requirements of their learners better by adopting the principles of CLT in their classrooms.

The above literature review focused mainly on the CLT principles as the teachers of the undergraduate colleges of Andhra Pradesh (AP) were trained at the Retraining Program on using these principles. Against the above backdrop, the paper examined CLT principles and techniques that were in place to develop students' English communication skills.

\section{Research Method}

The respondents of the study were the undergraduate students of first year at government and private aided degree colleges in Andhra Pradesh, India. They were randomly selected from those colleges which deputed their English teachers to undergo the Retraining Program. A total of 1500 male and female college students of 35 colleges in Andhra Pradesh took part in this study. The data was collected through a structured questionnaire. In 
addition, the researcher made use of classroom observation to collect more information. The data was collected 3-5 months after the teachers underwent the Retraining Program. Most of the respondents tend to look for jobs at call centers, IT and IT enabled services after they complete their college.

\section{Results and Discussion}

\subsection{Reasons for Studying English}

Motivation is crucial to success in language learning. The data indicated that majority of students (1140 of the 1500 wanted to learn English as 'it will be useful in getting a good job'.

It was clear that most students wanted to learn English for a practical benefit. Apparently, increasing demand for good English communication skills in job market was a major driving force.

\subsection{Type of Classroom Activities}

The type of activities that take place in the classroom can indicate whether the teaching/ learning situation is teacher dominated or learner centered. Majority of students (1275) opted for the choice 'teacher talking/lecturing', followed by 'students working individually'(1125), 'students working in pairs/groups'(705), 'students giving individual speeches/presentations(570)', 'group presentations'(510), 'role plays'(450), 'group discussions' (375) and 'all of the above'(165).

'Teacher talk' and 'student working individually' were the dominant classroom activities. However, the activities like presentations, discussions, and role plays were also reported modestly. This pointed to the fact that some 'beneficial' practices were also in vogue rather than depending only on the teacher talk. As CLT demands 'more student talk time', which was also stressed in the Retaining Program, the teachers should have put great emphasis on the same.

\subsection{Teacher's Focus}

What students learn has much to do with what teachers focus in their teaching. The respondents indicated that majority of their teachers focused more on developing their subject knowledge (55\%) as opposed to their English communication skills $(25 \%)$ or both $(20 \%)$.

As the students were required to be ready with good English communication skills to brighten their career prospects, teachers should have emphasized skill development as opposed to mere subject knowledge.

\subsection{Students Share Their Knowledge and Personal Experience}

Language learning can be made more purposive to learners by allowing them to share their knowledge and personal experience. The data indicated that $77 \%$ of students shared their knowledge and personal experience in the classroom, $19 \%$ said they did not share and $4 \%$ did not respond to this question.

Majority of students shared their knowledge and personal experience in the classroom. It was a beneficial practice and must have helped students to speak freely.

\subsection{Preference for Pair/Group Work}

Pair work and group work are essential features of a learner centered classroom. The data revealed that $64 \%$ of students wanted pair work and group work to be conducted in the class, $30 \%$ of students were not in favor of the same and $6 \%$ of the sample population did not respond to this question.

A good number of students opting for pair/group work was a sign of healthy language learning process.

\subsection{Teachers Monitor Students during Pair/Group Work}

Monitoring students during pair/group work will help students not to distract from the task and the teacher can also help if students seek any clarifications. $50 \%$ of students reported that their teachers monitored them during pair/group work, $46 \%$ of students said 'No' and $4 \%$ of the sample population did not respond to this question.

As monitoring was crucial to task execution, more number of teachers should have monitored their students while they were doing pair/group work.

\subsection{Teacher Simulates Real Life Communication in the Class}

Communication in the classroom that simulates real-life contexts such as how to shop or book tickets offers great motivation to learners. Moreover, language learning simulations provide students with the opportunity to learn the pragmatic skills of using language appropriately. The data revealed that of the 35 classes observed, in 9 (26\%) classes simulations were used and in $26(74 \%)$ classes simulations were not used.

Students learn to practice language that is close to real life communication in the classroom through simulations. 
Hence, more use of simulations was expected.

\subsection{Teacher Focuses on Giving Everyday Language Expressions}

Language learning becomes more meaningful to students if teachers give everyday language expressions in their classroom teaching. The data indicated that of the 35 classes observed, in $16(46 \%)$ classes teachers focused on everyday language expressions where as in $19(54 \%)$ classes teachers did not give language examples representative of everyday use.

Language samples representative of day to day life help students to use English for real life. Therefore, it was desirable that more number of teachers practiced this aspect on a wider scale.

\subsection{Teacher Uses the Skills of Listening, Speaking, Reading and Writing (LSRW) in Combination}

A critical feature of a communicative methodology is the use of the skills of LSRW in combination. When teachers teach language skills in integration, students will learn the language holistically. The data revealed that of the 35 classes observed, in 18 (51\%) classes teachers used the skills of LSRW in combination whereas in 17 $(49 \%)$ classes teachers did not use the skills of LSRW in combination.

Teachers can bring in more variety into their classroom teaching by the use of skills integration. Wider use of this activity was warranted in view of this fact.

\subsection{Teacher Uses Authentic Materials}

The use of authentic materials help learners to experience the feel of the language as a real language used for real life. The data revealed that of the 35 classes observed, in $7(20 \%)$ classes teachers used authentic materials whereas in $28(80 \%)$ classes teachers did not use authentic materials.

Failure to use authentic materials could probably be attributed to teachers' over dependence on the textbook. Since authentic materials present students with samples of language used for real life, much wider use of them was expected.

\subsection{Teacher Handles Practical Problems}

Implementing CLT principles in the Indian setting was beset with difficulties such as large classes, lack of textbooks with the students, and lack of infrastructural facilities. The data revealed that of the 35 classes observed, in $16(46 \%)$ classes teachers were successful in tackling practical problems whereas in $19(54 \%)$ classes teachers were not successful in tackling practical problems involved in implementation of CLT.

Though nearly fifty per cent of the teachers were not able to overcome some of the practical problems involved in the implementation of CLT, it was heartening to note that a good chunk of teachers did succeed in doing so. Measures must be taken by the authorities concerned to help teachers have a more conducive atmosphere so that required competencies can be developed in students more effectively. At the same time, teachers also needed to use more innovative practices to overcome some of the common practical problems.

\subsection{Teaching/Learning of Listening Skills}

Effective communication is possible only if one is a good listener. The data indicated that majority of students (1095) improved their listening 'by listening to the teacher as he/she read out and explained the text'. The data also revealed that a considerable number of students (780) improved their listening 'by making notes as they listened to the teacher's explanation of the lesson'. The responses also indicated that 705 students had an opportunity to improve their listening 'by listening to their classmates when they talk in English in the class'.

Majority of the students improved their listening skills by listening to teacher while reading out the text. Heavy reliance on this technique was understandable given the limited/no exposure they have had outside of classroom for practicing listening.

\subsection{Teaching/Learning of Speaking Skills}

Present day job market opens up many opportunities for the graduates with good spoken ability. The data revealed that majority of students (1050) improved their speaking 'by taking part in role plays, games, debates, group discussions'. The data also revealed that a considerable number of students (1005) improved their speaking 'by raising their doubts and by way of responding to teacher's questions'.

Teachers should be commended for helping learners develop their oral proficiency in a 'beneficial' manner.

\subsection{Teaching/Learning of Reading Skills}

Good reading comprehension ability is critical to students' academic success. Reading is also considered valuable because the reader has more control over the language input than in the case of listening, where much 
of the control is with the speaker. The data showed that majority of students (1035) improved their reading 'when their teacher reads aloud and explained the lesson in English'. The data also revealed that a considerable number of students (855) improved their reading 'when their teacher read aloud the passage and translated into mother tongue'. The responses also indicated that 780 students practiced reading 'by reading the text aloud in turns and then doing the exercises'.

Majority of students improved their reading skills when their teacher read aloud and explained lessons. Reading a passage aloud, when pacing and pausing are appropriately used, helps promote quicker understanding of lessons for students. However, it was not a good strategy as teaching/learning process turned heavily teacher-centered. Teachers should have used more 'beneficial' strategies to develop their students' reading ability.

\subsection{Teaching/Learning of Writing Skills}

Ability to write well is as important as oral proficiency for students at the undergraduate level. The data revealed that majority of students improved their writing skills' by writing on a topic given by the teacher'. The data also indicated that a considerable number of students improved their writing 'by thinking and sharing their ideas in pairs/groups on a topic before they write.'

Majority of students improved their writing skills by writing on a topic given by the teacher. As such writing activities 'force' the students to write something without purpose and audience in mind, less frequent use of them was desirable.

\section{Conclusion}

The results of this study yield some pedagogical implications in terms of how the strategies of the faculty have to be while following CLT features in their classrooms and what administrators need to do to facilitate better learning. The pedagogical implications are as follows:

a) Teachers should lay great emphasis on skill development rather than subject knowledge and follow more learner centered ways of instruction.

b) Teachers should ensure more variety in their classroom activities and teach language skills in integration.

c) Teachers should emphasize the use of authentic materials and language learning simulations.

d) Teachers need to provide language expressions that could be of use to students in their day to day life.

e) Teachers should use more 'communicative' activities for enhancing their students' listening, reading and writing abilities.

f) Administrators must make resources such as text books, computers, and photocopy machines readily available to the teachers and students.

g) Administrators should conduct programs such as the Retraining Program periodically so that teachers can share their successes and difficulties with the implementation of CLT principles.

\section{References}

Bachman, L. (1990). Fundamental Considerations in Language Testing. Oxford: Oxford University Press.

Berns, M. S. (1990). Contexts of Competence: Social and Cultural Consideration in Communicative Language Teaching. New York: Plenum.

Canale, M. (1983). From Communicative Competence to Communicative Language Pedagogy. In J. Richards, \& R. Schmidt (eds.), Language and Communication, 2-27. London: Longman. http://dx.doi.org/10.1093/elt/37.2.111

Canale, M., \& Swain, M. (1980). Theoretical Bases of Communicative Approaches to Second Language Teaching and Testing. Applied Linguistics, 1(1), 1-47. http://dx.doi.org/10.1093/applin/1.1.1

Kiato, S. K., \& Kiato, K. (1996). Testing Communicative Competence. The TESOL Internet Journal, 2(5).

Larsen-Freeman, D. (1986). Techniques and Principles in Language Teaching. Oxford: Oxford University Press.

Lindsay, C., \& Knight, P. (2006). Learning and Teaching English. Oxford: Oxford University Press.

Littlewood, W. (1981) Communicative Language Teaching: An Introduction. Cambridge: Cambridge University Press.

Nunan, D. (1989). Designing Tasks for the Communicative Classroom. Cambridge: Cambridge University Press.

Nunan, D. (1991). Communicative Tasks and the Language Curriculum. TESOL Quarterly, 25(2), 279-295. 
http://dx.doi.org/10.2307/3587464

Richards, J. C. (2006). Communicative Language Teaching Today. Cambridge: Cambridge University Press.

Richards, J. C., \& Rodgers, T. S. (1986). Approaches and Methods in Language Teaching. Cambridge: Cambridge University Press.

Widdowson, H. G. (1990). Aspects of Language Teaching. Oxford: Oxford University Press. 